\title{
The Lengthening of Life: The Importance of Context and Life Course
}

\author{
Sarah Harper ${ }^{1}$
}

Published online: 30 August 2018

(C) Springer Nature B.V. 2018

This month saw the launch in Paris of the latest collection edited by the sociologist, Anne-Marie Guillemard. Professor Guillemard is now Professor Emeritus of Sociology at the Faculty of Social and Human Sciences, University of Paris Descartes Sorbonne, following a long and distinguished career researching and writing on the sociology of ageing and the life course. She was awarded the Chevalier de la Légion d'honneur in 2002. Her latest collection Allongement de la vie: Quels défis ? Quelles politiques? (Lengthening of life: What challenges? Which policies?) is published by La Découverte (2017) and edited jointly with Elena Mascova.

The collection explores how the lengthening of human life is revolutionizing the 21 st century on all continents, yet the scale of these changes and their many implications remain largely unknown. The collection of essays and research papers book provides an overview of the disruption of the human and social condition, the temporal regime of our lives, as well as the ways of living together. In a society where four generations now coexist with significantly different experiences and aspirations, forms of solidarity need to be rethought. Similarly, how should one protect and care in longlived societies? What is the meaning and the price of prolonging life? How do we reconcile longevity and quality of life? Professor Guillemard argues that it is only through the cross-fertilization of multidisciplinary approaches and from a perspective of international comparisons, that we can begin to comprehensively reflect on the question of longevity.

As a contributor to the collection, I was honoured to be invited to present the lecture "L'impact de l'équilibre du travail et des soins tout au long de la vie sur le bien-être des femmes à la retraite et les régimes de protection sociale qui contribuent à façonner cette" celebrating the launch of the collection. What follows is an English translation of part of that lecture which emphasises the necessity of combining life course analysis

Sarah Harper

sarah.harper@ageing.ox.ac.uk

1 Oxford Institute of Population Ageing, University of Oxford, Oxford, UK 
with the context in which it occurs if we are to comprehensively understand the drivers of health and wellbeing within our increasingly long lives.

The impact of work-life balance and lifelong care on the well-being of retired women and the social protection systems that help shape this ${ }^{1}$.

It has been long recognised that the individual life course has a significant impact upon both mental and physical health and wellbeing in later life. Research has established that favourable conditions in early and mid life are associated with good health and well being in later life, while unfavourable conditions negatively influence the possibilities of health and wellbeing in the third and fourth ages. Furthermore, research has indicated that an individual's employment and family obligations have a significant impact on health and well being across one life. Many studies have emphasised the accrual of risk for mental and physical health, which arise from poor working conditions for example. In particular, economic employment is the main determinant of the financial circumstances in retirement and often influences access to good standards of medical care later in life, additionally work meets basic psychosocial needs. Thus, economic employment provides a sense of belonging to a social network, a feeling of control and autonomy, and a sense of reward.

The difference in these experiences between men and women is particularly interesting, as women are often more negatively affected by the employment experience. Despite social change and the rapid entry of women into the labour market in recent decades, women continue to play a major role in household management and care for family members. In general, men have not increased their contribution to domestic tasks to compensate for the increase in women's participation in the labour force outside the home. Women are therefore more vulnerable than men to the stress of informal care. As a result, male life courses are still predominantly characterized by progressive full time employment, while women's trajectories are more diverse and most women still combine economic employment with domestic duties. There is evidence that domestic tasks alone have a negative impact on women's mental health, but those women who had worked full time also had the best health and quality of life in retirement.

This lecture reports on research by Zella and Harper (2018) which argues that the association between women's labour market trajectories and their health is framed by the context in which they live. Indeed, the relationship between the labour market and health care is characterized by different labour market interventions and family-friendly policies. Yet here has been little explicit research to analyse the association between work trajectories and health outcomes in different settings. It is therefore important to examine the role of the combination of family life and working life for women living under different European welfare regimes.

This leads us to 3 hypotheses: (i) the work and care histories of women are predictive of their future health; (ii) women who reconcile paid work and domestic chores (home work and family care) have better physical and mental health later in life; (iii) the state welfare context plays an important role in shaping the relationship between occupational trajectories and women's health. There are thus two sub-hypotheses: (iiia) women who worked economically full-time in welfare regimes which

\footnotetext{
${ }^{1}$ L'impact de l'équilibre du travail et des soins tout au long de la vie sur le bien-être des femmes à la retraite et les régimes de protection sociale qui contribuent à façonner cette, Lecture presented at the launch of Allongement de la vie: Quels défis ? Quelles politiques? Paris June $12^{\text {th }} 2018$
} 
facilitated and supported dual careers, typically in northern European countries, would have better well-being in later life than women who undertook full-time work in family based regimes. Alternatively (iiib) women who have devoted themselves exclusively to domestic tasks, typically in the southern European countries, would have better wellbeing later than those who undertook full time domestic tasks time in Nordic countries.

To test these hypotheses, we analysed data from the Survey of Health, Aging and Retirement in Europe (SHARE), an international panel survey that provides comparable information on the health, social conditions and employment of 50-year-old Europeans and more. Six longitudinal waves from 2002 to 2013 were analysed, selecting women who had retired during this period.

The 12 countries were organized into four welfare regions following Neyer (2013).

i. Social Democrats - high levels of dual career employment, moderately high levels of family allowances, childcare and leave, and "reproductive" work allocated to the state. (Denmark and Sweden)

ii. ii. Liberal - low levels of traditional family support and dual career support, with "reproductive" work considered a private responsibility. (Ireland and Switzerland)

iii. Continental - low levels of support for women's participation in the labour market, average provision of childcare services, high family allowances. (Austria, Belgium, France, Germany and the Netherlands)

iv. Famialistic - asymmetric distribution of work between the sexes, low participation of women in the labour market, and implicit support for the essential role of women as caregivers, with poor family services and state subsidies. (Greece, Italy and Spain)

The complete dataset was used in the first set of data analysis to create labour market histories using sequence analysis. The second set of analyses explores the association between employment history, social protection schemes and two health outcomes (EURO-D and self-reported health) after leaving the labour market.

Women who never participated in the labour market were more likely to report both higher depressive symptoms and poorer health later in life. Women who have reconciled professional life and family tasks have better health and less depression. Regarding the role of the welfare state we found that women in social-democratic countries report being healthier than women in other regimes, while women in social-democratic countries and in liberal regimes had lower depression

The role of the welfare state is particularly interesting. While our first welfare state hypothesis - women who worked full-time in dual career typically Social Democratic regimes would have better well-being later in life than women who undertook this profile in famialistic regimes - was confirmed, our second - women who undertook full-time domestic tasks typically in famialistic southern European countries would have better well-being in later than those who undertook them in social democratic regimes - was not confirmed.

In both the famialistic and the continental countries, not only are women at higher risk of poor health and depressive symptoms, but this situation is stronger for women who have spent all their active years exclusively in domestic tasks. Indeed, being active in the job market with a full-time job or a mixed career increases the chances of a better well-being in later life in all regimes. 
Therefore, for women who have paid work under a regime that supports this both through societal policies and attitudes, have better health outcomes. However, an exclusively domestic occupation under a regime that supports this both through societal policies and attitudes does not result in better health outcomes. The combination of paid work with domestic chores provides the best health and well being outcomes for women regardless of the social protection system, and these outcomes are highest under regimes which that support and facilitate this combination.

Our research therefore suggests that women who have never participated in the labour market are more likely to report higher symptoms of depression as well as poorer health later, while women who have combined work and household tasks have better health and well-being. In addition, living and working in a social protection system that supports this combination enhances these outcomes. Alternatively, women who undertake domestic tasks while working full-time throughout their lives have the most negative results, with the highest risk of depression.

France, with its high percentage of older women who have worked all their lives or engaged in domestic tasks with paid work, is currently in a good position. It is therefore important that future decisions regarding the role of women in society and the workplace take these findings into account and that woman continue to successfully combine economic and domestic employment in a supportive environment.

\section{References}

Guillemard, A. and Mascova, E. (2017). Allongement de la vie: Quels défis ? Quelles politiques ?. Paris: La Découverte.

Neyer, C. (2013). Welfare States, family policies, and fertility in europe. The Demography of Europe, pp, 29-53.

Zella, S. and Harper, S. (2018). The impact of different work/care life courses on women's wellbeing in early retirement and the welfare regimes which help shape this. Oxford Institute of Population Ageing. 